\title{
DEVELOPMENT OF THE ECONOMIC SOCIAL AND ECONOMIC DOCTRINE IN THE WORKS OF MUSA AKIEGETZADEH AND USE OF ITS PROVISIONS IN DEVELOPMENT OF STATE REGULATION MEASURES FOR MULTIPOLAR ECONOMY
}

Aidar M. Tufetulov ${ }^{1}$ Gulnara N. Hadiullina ${ }^{2}$ Andrey S. Zayats ${ }^{3}$

\begin{abstract}
Development of the Russian economy is accompanied by qualitative changes in the ethnonational sphere, what is manifested in the growth of the scales of integration processes, formation of interethnic and supranational regional civilizational communities and megaethnoses. The objective basis for these changes lies in the material and spiritual culture of peoples, but, as the practice of ethnonational relations shows, they come in a contradictory and painful way, what makes it necessary to take them into account when forming measures for state regulation of the economy. At present, Russian society needs a new scientific paradigm reflecting the
\end{abstract}

positive direction of development of national relations in the country and taking into account the experience of centuries-old cooperation between nations and peoples. The article presents an analysis of the main provisions and conclusions contained in the works of Moussa Akiegetzadeh, the creator of the first major art work in the Tatar language of the last quarter of the 19th century and the founder of the system of economic views, in which the achievements of world and Russian economic science, as well as Islamic traditions were synthesized, and popularizer of these ideas in the Ottoman Empire in the era of Mesrutiat (Parliamentarism) and the following years. The thesis is

\footnotetext{
${ }^{1}$ Kazan Federal University. E-mail address: verkbund@gmail. Com. Tel. : +7 (906) 3219099

${ }^{2}$ Kazan Federal University. E-mail address: verkbund@gmail. Com. Tel. : +7 (906) 3219099

${ }^{3}$ Kazan Federal University. E-mail address: verkbund@gmail. Com. Tel. : +7 (906) 3219099
} 
substantiated, according to which historical and economic knowledge acts as one of the sources for elaboration of the program documents of the Russian state in formation of regional development targets; the possibility of their realization is being determined by complete inclusion of the totality of cultural, historical, social, religious features of territorial entities.

Keywords: history of economic doctrines, historical and economic knowledge, Musa Akiegetzadeh(18641923), Islamic economy, classical school of political economy, German historical school, etatism, kemalism, protectionism, economic policy of the state.

\section{Introduction}

The desire to master the latest achievements of world science and develop new approaches to the study of certain social and economic phenomena, which can become the starting point for formation of effective economic policy in the regions, as well as the desire to revive the memory of thinkers of the past, who gave us an example of selfless service to the truth. All this predetermined the choice of the topic of research and an appeal to the history of economic thought, elucidating its place and role in the life of the Tatar people, studying the personal contribution of its prominent representatives in the development of domestic and international economic thought.

The historiographic study base includes works by Tatar scholars who study development of socio-economic thought in the Tatar society and the biography of a number of personalities; works of Tatar scientists and public figures M. Akiegetzadeh, Yu. Akchura, S. Maksudi, G. Faizkhanov, G. Bayazitov, M. Bigi, G. Gubaidullin, I. Gasprinsky, R. Ibrahim, F. Karimi, R. Fakhretdin, and others; periodic printing of Muslims in Russia and abroad.

A comprehensive analysis of the socio-economic views of the Tatar foreign diaspora's representatives predetermined the multifaceted nature of the research methodology, the need to use a number of specific methods and techniques that complement each other and allow one to fully disclose the goals and objectives: systematic, statistical, comparative historical and logical 
analysis, laws and principles of dialectics. Historical and economic processes are considered in the work from the position of the civilizational approach.

\section{Methods}

Musa Akiegetzadeh (or Musa Akieget, or Musa Akteregoglu) has a special place in the history of world economic thought not only as a thinker who managed to create an economic system in which the achievements of the world and Russian economic science, as well as Islamic traditions are synthesized, but also as a popularizer of these achievements in the Ottoman Empire of the Young Turks. As modern Turkish researchers recognize his creative heritage, economic science in Turkey did not develop before the appearance of the works of M. Akieget $[6 ; 127]$.

We know of 3 of his works published in Turkey. The first work, "Avrupa medeniyetine bir nazar" ("One look at European culture (civilization)") was published in 1898 (1314 old style) in Istanbul in the publishing house of Jemal Efendi, Bab-y-Ali district. In 1906, this work was published in Russia in the journal "Algasreldzhadit" [9; 15] issued in Uralsk. In 1996, in the city of Ankara Turkish Religious Foundation in the series "Read and Think" published the work of M. Akiegetzadeh again, translated into modern Turkish. The preface written by R. Seichuk Uysal [4; 127] describes the author's life path and determines the significance of his works for formation of the consciousness of the Turkish society at the Mesrutiat (Parliamentarism) era.

The second work "Iktisat yahut ilmi seruet: Azadegi ticaret ve usuli himaya" ("Economics, or the science of wealth: Free trade and ways to protect it (protectionism)") in the volume of 62 pages was published in 1899 (1315 old style) in the printing house of the Military Publishing House "Karabat" (Istanbul, st. Babe Ali). This work was written in Old Ottoman and was not reprinted later. Several archival works by M. Akiegetzadeh have been preserved in the archives of the Suleymaniy library in Istanbul.

The third work "Ilmi seruet vuyahut ilmi iktisat " ("The Science of Wealth, or the Science of Economics") had a second, explaining title: "The book 
contains important economic information". It dates back to 1900 and was also printed in the printing house of the Military Publishing House "Karabat" (Istanbul, st. Babe Ali).

\section{Results}

M. Akiegetzadeh devoted a significant place to the study of A. Smith's principle of an "invisible hand". At the same time, the author rejects the vulgar interpretation of this principle according to which the spontaneous coordination of interests occurs in the market conditions, and repeatedly emphasizes that the motive power of personal interest acts in accordance with the interests of society only under certain institutional conditions.

The fulfillment of these duties requires a very large variety of costs, "which for the most part have to be covered by taxes of one kind or another" $[10 ; 151]$.

M. Akiegetzadeh considered increasing in the level of general and special education as one of the most important sources of economic growth, since the work of an educated and professionally trained person is more
108

productive than that of untrained workers. This led him to the conclusion about the need for public primary and secondary education using charitable contributions of individuals, public (religious) organizations and business structures. Concerning higher education, he defended the idea of mixed financing (private and public), substantiating this provision, first, by the limited state budget, and secondly, by the need for additional incentives for knowledge acquisition by those who pay (partly or completely) for their education $[28 ; 38$, 42].

The influence of the German historical school on M. Akgehetzade's economic views was manifested in the appeal to the analysis of various noneconomic factors: ethical, political, psychological and legal, which operation guarantees the effective functioning of market signals. "In addition to economic interests, there are other high goals (interests). These are political and national interests, traditions, national culture and others. By observing these interests, people retain their high position in society and win (deserve) national supremacy (victory). Thus, it goes to that it is necessary to live and 
make choices for the good of your nation" [9; 151].

M. Akiegetzadeh often referred to the work of Friedrich Liszt "The National System of Political Economy" (1841), who had formulated the principle of "educational protectionism" aimed at supporting the factory industry. As is known, F. Liszt distinguished the following stages of development in the progressive evolution of a national economy: a) the stage of savagery; b) the stage of the shepherds; c) the agricultural stage; d) agricultural and manufacturing stage; e) agricultural, manufacturing and trading stage [8].

M. Akiegetzadeh recognized the positive role of trade unions in contemporary society. They prevented the realization of monopolistic tendencies among employers which can unite in the issue of determining wages and set it below the level allowed by competition. "The number of trade unions of workers is increasing every day in England and in other European countries. In our opinion, this issue is vital... The unions of Western workers are engaged in settling conflicts related to wages as a result of a change in supply and demand for workers. But due to the fact that a small number of workers are included in these unions, they can not achieve a permanent increase in wages" [2; 180].

Recognizing the effect of the J.B. Say's law and, therefore, denying the possibility of a general crisis of overproduction, M. Akiegetzadeh pointed out the possibility of imbalance in individual markets, which is caused by the rapid accumulation of capital and the creation of such an amount of production capacity that exceeds the volume of market demand. On the surface of economic life, crises are manifested in inflation and unemployment. Unlike representatives of the classical school of political economy, M. Akiegetzadeh considered certain aspects of antiinflationary regulation of economic processes [2; 109], as well as labor market regulation. By the author, the problem of overcoming unemployment is considered from the position of the Islamic concept of the world order according to which both conscious and forced idleness is condemned. The position of the work is that the society should provide its members with the opportunity to earn means for their own existence, taking into account their 
wishes and recognizing the equal right to work [2;179-182] are perceived by us as declarative, because they are not supported by any serious recommendations of the author on their implementation.

M. Akiegetzadeh associated overcoming and preventing the crises of the market economy with the activities of the state, in particular, with the implementation of the principles on proportional development of individual territories and industries, primarily industry and agriculture. In the opinion of the author, this principle should become the central link of the "regional physical plan" $[1 ; 48]$. This category was used by him in the analysis of the state's foreign economic policy and in the critical analysis of certain provisions of the Liszt system. Indicative planning serves as a main lever that allows solving the problem of equal growth rates of industrial and agricultural sectors. "...The method of protection is not dominant. This is just a measure adopted to develop and strengthen the productive power of one state" $[1 ; 48]$.

The study of the principles for the budget construction and use allows the author to draw a conclusion about the advantages of taxation over internal and external borrowings as ways of replenishing income. Analyzing the policy pursued by the Ottoman state of expanding external loans, $\mathrm{M}$. Akiegetzadeh relied on the classical postulate on the unproductive use of productive labor in this case $[2 ; 42,152]$.

In accordance with the principles of the social Islamic concept, as an important function of taxes, the author considers not the replenishment of the budget, but the stimulation of the demand for investment and employment. At the same time, he repeatedly emphasized the need to comply with the principle of transparency in the construction of the state's tax system, and also pointed to the educational role that taxes should play in the economic system [2; 201].

\section{Discussion}

As is known, the program speech of the President of the Turkish Republic Kemal Ataturk at the Izmir Economic Congress in 1924 did not contain etatatist principles [7; 194-202]. This was due to the peculiarities of the 
concrete historical situation in the country.

Thus, the policy of "milli iktisat" ("national economy") proclaimed by the Kemalist government may be viewed by us as a policy of moderate etatism which differs significantly from the policy of active state regulation that Turkey addressed in the 1930s. The Kemalist authorities' adherence to such a contradictory concept of economic policy is explained by the following reasons:

1. A comprehensive program of state regulation of the economy could not arise immediately after the end of the war, since it took time to develop it;

2. The policy of "milli iktisat" was an expression of extremely contradictory interests in Turkish society.

3. It is necessary to recognize the existing economic and political measures of pressure from the European powers.

4. In Turkish society, there were unjustified hopes for USA and European investments, primarily in the industry and market infrastructure, as well as Turkey's "equal" cooperation with the economically developed powers.
5. In the opinion of most researchers, the main factor that was predetermined by liberal measures within the policy of "milli iktisat" was the position of the commercial bourgeoisie which has been interested in maintaining low import duties (primarily cotton fabrics), what ensured high revenues from imports $[5 ; 17-19]$ and lobbied this decision in the Supreme Economic Council under the government. The consequence of such government measures was a change in the structure of GDP in 1928-1929, namely: the share of industrial products fell from 13.6 to $9.9 \%$ due to the growth of the share of agricultural output $[5 ; 21$, 22].

The consequence of these factors was the inconsistency in the economic policy of the Kemalist government in the early years of the republican government, which allows some researchers to view them as a period of a "laissez-faire economics" [3; 3]. Thus, etatism is a broad and multipurpose interference of the state in the life of a society with ambiguous goals, but in general it contributes to formation of market structures. The core of etatist measures is the economic interaction of 
the state and society in the conditions of transition from a traditional society to a modern one.

\section{Summary}

The study allows us to determine the differences between the medieval economic system of the Ottoman Empire and the states of the East from the classical Western European model of feudalism, which consists in dismembering the functions of landownership, dismembering the property relations into two spheres: the supreme and taxation, and in the special role of the state which acted as a supreme land owner. Forms of realization of this right were a special character of rental relations, a high degree of dependence of subordinate subjects of economic relations on the state, a particular mode of urban economy, and so on. It should also be noted the active role of the state in the Islamic concept of the world order, according to which it is viewed by Islam as an obligatory attribute of an economic system.

The factors listed above predetermined the appeal of Musa Akiegetzadeh to the question of the nature, forms and extent of state intervention in economic processes. To justify the need for state regulation, the author leads into the economic analysis of a category that, from the standpoint of modern economic science, can be viewed as public goods and externalities. Recognizing the principle of an "invisible hand of the market", the author simultaneously pointed out that the motive power of personal interest acts in accordance with the interests of society only under certain institutional conditions.

Recognition of "market failures" led M. Akiegetzadeh to the need to study the problem of the causes of economic crises and forms of anticrisis regulation. Crises were interpreted by him as a violation of balance in individual markets, manifested in the rapid accumulation of capital and the creation of such an amount of production capacity that exceeds the volume of market demand. The author associated overcoming of the crisis phenomena with the corrective measures of a state, which consist in development of a "regional physical plan" and ensure the proportional development of industries and regions. 
M. Akiegetzadeh considers the fiscal policy as a measure of state regulation of the economy. The author's interpretation of the taxation and budgeting principles shows the author's adherence to the classical principles of economic science. The analysis of credit systems allows the author to formulate the idea of stateization of a number of banks, which should normalize monetary circulation and accelerate the process of concentration of public and private savings, and stimulate investment demand.

\section{Conclusions}

Thus, the economic system of M. Akiegetzadeh viewed by us as a result of development of the traditions of world and Russian economic thought, is an original symbiosis of the principles of the classical political economy school, the German historical school, and the provisions of the Islamic social and economic doctrine which manifests itself in recognizing the effectiveness of the market mechanism under provision of broad and multi-purpose interference of the state in all spheres of society; denial of the universality of economic laws and the recognition of the national economic

system characteristics primacy in the development of the economic policy of the state; increased attention to political, legal, ethical and socio-political factors of economic development.

In turn, in the context of formation of a multipolar world, consideration of the specific features of territorial entities within which state (regional) regulation measures are implemented, ensures the effectiveness of control measures. Mastering historical and economic knowledge makes it possible to form multicultural competences as a necessary element of human potential, on the condition of which the effectiveness of management decisions aimed at ensuring sustainable socio-economic development of a multinational state and its constituent regions depends.

\section{Acknowledgments}

The work is performed according to the Russian Government Program of Competitive Growth of Kazan Federal University.

\section{Bibliography}


Akyigitzade M. Iktisat yahut ilmi seruet:

"Azadegi ticaret ve usuli himaya"

("Economics, or the science of wealth:

Free trade and ways to protect it (protectionism)"). - Istanbul, 1898.

Akyigitzade M. Ilmi seruet vuyahut ilmi iktisat "("The Science of Wealth, or the Science of Economics "). - Istanbul, 1900.

Boratava K. Turkiye'de devletcilik. Ankara, 1982. Selcuk Uysal R. Yayina hazirlayanin onsozu//Akyigitzade $\mathrm{M}$. Avrupa medeniyetine bir nazar. Ankara:Turkiye diyanet vakfi yayinlari, 1996. - IX-X b.

Selcuk Uysal R. Yayina hazirlayanin onsozu//Akyigitzade M. Avrupa medeniyetine bir nazar. Ankara:Turkiye diyanet vakfi yayinlari, 1996. - IX-X b.

Sonmez M. Turkiye ekonomisinde bunalim. 2 kitab. - Istambul, 1982. Pp.17-19.

Teufik Caudar. Turciye'de liberalism. Ankara, 1992. - 127 p.
Turkiye iktisat Kongresi. 1923 - Ismir. Ankara, 1967. Pp.194-202.

Liszt F. National system of political economy. - St. Petersburg., 1891.

Musin F. Musa Akieget // Tatar edebi tarhi. Alty tomda. - Kazan kitap Nashriyaty, 1985. - In 2 volumes - 15 p.

Smith A. Research on the nature and causes of the wealth of peoples. - In 2 volumes. - Moscow: OGIZ, 1935 